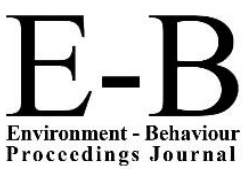

\title{
AicE-Bs2016Edinburgh
}

$7^{\text {th }}$ Asia-Pacific International Conference on Environment-Behaviour Studies, St Leonard Hall, Edinburgh University, United Kingdom, 27-30 July 2016

\section{Heritage Conservation Management in Egypt: The balance between heritage conservation and real-estate development in Alexandria}

\author{
Dina Mamdouh Nassar ${ }^{*}$ \\ ${ }^{1}$ Architectural Engineering Department, Faculty of Engineering, Alexandria University, Abu Qir St., Ibrahimiya, Alexandria 11432, Egypt
}

\begin{abstract}
Old cities face many challenges in the search for a better quality of life. They have an obligation towards their past, as they grow and develop. They should not lose their identity or destroy their history. In Egypt, and especially in Alexandria City, the battle between heritage conservation and real estate investment exists and raging. Are we obliged to keep old buildings although they have lost their original settings?

The debate of either keeping or demolishing some of the heritage stock to make way for new real estate development is argued in this research at the administrative, public and private levels. This research took into consideration the situation of real estate investments and building laws in Alexandria in the last nine years, since the establishment of the Technical Secretariat of the Standing Committee of the Heritage Conservation Commission in Alexandria. The discussion aims to point out the problems and clarify how to manage heritage buildings in Alexandria and at the same time maintain steady real estate investment. The research also presents a case study on the current building situation in the municipality of San-Stefano, where some heritage buildings are listed while the majority of the area is modernised.
\end{abstract}

(c) 2016. The Authors. Published for AMER ABRA by e-International Publishing House, Ltd., UK. This is an open access article under the CC BYNC-ND license (http://creativecommons.org/licenses/by-nc-nd/4.0/).

Peer-review under responsibility of AMER (Association of Malaysian Environment-Behaviour Researchers), ABRA (Association of Behavioural Researchers on Asians) and cE-Bs (Centre for Environment-Behaviour Studies), Faculty of Architecture, Planning \& Surveying, Universiti Teknologi MARA, Malaysia.

Keywords: Heritage Conservation Management; Heritage Buildings Inventory; Real Estate Investment; Public Interest.

\section{Introduction}

The conservation of heritage is one way for old cities to look up to a sustainable future. However, with rapidly changing markets and inflexible legislative systems, this improvement needs motivation. How to reach a proper balance in the correlation between conserving heritage and real estate development is the issue discussed in this study.

\footnotetext{
*Tel.: +20100-652-0526

E-mail address: dnassararch@yahoo.com
}

2398-4287 @ 2016. The Authors. Published for AMER ABRA by e-International Publishing House, Ltd., UK. This is an open access article under the CC BY-NC-ND license (http://creativecommons.org/licenses/by-nc-nd/4.0/).

Peer-review under responsibility of AMER (Association of Malaysian Environment-Behaviour Researchers), ABRA (Association of Behavioural Researchers on Asians) and CE-Bs (Centre for Environment-Behaviour Studies), Faculty of Architecture, Planning \& Surveying, Universiti Teknologi MARA, Malaysia.

DOI: http://dx.doi.org/10.21834/e-bpj.v1i4.132 
Whether it is for reviving the community or for protecting the environment, how people value and appreciate cultural heritage is a matter that must be taken into consideration in the heritage conservation system. Considering that people's preferences toward heritage buildings and places are key factors to what should be preserved and how to do it (Mason, 1998).

The conceptual idea of heritage conservation is more or less focused on the desire of keeping unique values such as; a Historical era, National figure or significant architecture for future generations. The decision to demolish heritage buildings is considered critical; their value cease to exist, and it erases parts of tangible history, making way for future developments. The consequences of this act may not appear straight away, but as time goes by, all evidence of the past will have faded away. The human's desire for knowledge of the past will leave them with the difficulty of re-imagining a gap in history. The idea of heritage conservation relies on the community and their appreciation towards it. There are many reasons behind the failure of rehabilitation projects; some of which include abandonment and neglect, possibly leading to gentrification. The counter argument in this research is about the completely modernised street fabric in many old neighbourhoods, where there is no physical evidence of the past, except for some scattered old listed villas. The presented case study discusses the situation at the 'San-Stefano' neighbourhood in Alexandria where almost all evidence of its heritage disappeared.

Previous studies have shown that adaptive reuse can provide a sustainable future for heritage buildings (Bullen, 2007) (Hilde Remoy, 2015). Many have focused on the satisfaction of occupancies in refurbished historical buildings (Ahmad Ezanee Hashim, 2012), others have focused on managing historical assets (Aidatul Fadzlin Bakria, 2012). Researchers seemed to overlook the needs and the economic situation of the local context. Preserving heritage buildings is widely considered a cultural luxury compared to development challenges such us hunger, health or poverty deemed of primary importance practice (Christian Barillet, 2006), the majority do not appreciate social benefits. Far from being what could be regarded as a superfluous luxury in comparison with the basic needs of most developing countries, all actions promoting the cultural heritage can serve as a starting point for development. Therefore, studies must analyse local cases to answer the question of how heritage conservation and real-estate development can co-exist.

\section{Methodology}

This research discusses the heritage management system in Alexandria on the administrative, applicative and social levels. It criticises the way by which the heritage conservation administration set up the list of heritage buildings in Alexandria in 2007 (Harmony, 2009). The study uses the case of 'San Stefano' neighbourhood to present the current situation of the built environment in Alexandria, to analyse the heritage management system with regards to social and physical changes in the area.

The research will suggest how to modify the list to become compatible and consistent with the needs of owners, users and investors. It attempts to clarify the argument between both heritage conservation and real estate investment.

\section{Literature Review}

\section{The Modern Heritage Management in Egypt}

The International Program on Modern Heritage was launched in 2001 by the UNESCO World Heritage Centre, ICOMOS and DOCOMOMO. This joint program for the identification, documentation and promotion of the built heritage of the $19^{\text {th }}$ and $20^{\text {th }}$ centuries focuses on raising awareness concerning the heritage of architecture, town planning and landscape design of the modern era. It is considered to be particularly vulnerable because of weak legal protection and low appreciation among the general public. (Nations, 2001) 
The modern architectural heritage in Egypt is presented in a group of buildings, streets and areas of outstanding value. They form Egypt's modern urban cultural civilisation, and they are considered national wealth. Two Egyptian laws and their legislations govern and protect the modern architectural heritage in Egypt, which differs from the National Monument Preservation known as "Law No. 117 of the year 1983". These laws emerged in the $21^{\text {st }}$ century. Section 2 of the building act of 2008 called "Law No. 119 of the year 2008", consists of three chapters that regulate the works of the National Organization of Urban Harmony, Areas of Outstanding Value, Advertisements, and Signboards in eleven articles (Harmony, 2009). Regulations of "Law No.144 of the year 2006" consist of two chapters that regulate the Demolition of Unthreatened Buildings and the Conservation of the Architectural Heritage, presented in 16 articles (Presidency, 2008).

Nevertheless, Egypt's Modern Architectural Heritage witnesses a state of deterioration. Conservation needs handling through a scientific and orderly process for building maintenance, preservation, adaptive reuse, compensation policy and sustainable development. Therefore the need to involve decision-makers with building owners, users and investors are mandatory. The goal should be to achieve common financial and social benefits.

\subsection{The National Organization of Urban Harmony (NOUH)}

The NOUH Authority established in 2001 by "Decree No. 37 /2001". The idea was to form a body responsible for addressing the cultural gap between the official based references through artists, designers and the community in shaping the image of the city, to meet at the level of awareness of the aesthetics of urbanisation and to reformulate the vision of future architecture in the city. The foundation aims at applying the values of beauty to the exterior image of buildings, urban and monumental spaces. Guidelines for the standards of Urban Harmony for heritage buildings and areas are published by the Supreme Council for Planning and Urban Development, according to "Law No. 119 of 2008" and its executive regulations. NOUH is authorised to make all necessary decisions and recommendations by the current law and legislation. Hence, it is responsible in particular for the following (Culture, 2001):

- Formulating visual beauty for urban areas all over Egypt by eliminating actual irresponsible developments.

- Preparing a database comprising all buildings with significant architectural values and setting the necessary regulation to preserve this heritage.

- Adopting norms that guarantee no alteration to the current image of old cities, and prohibiting harmful additions to its existing building fabric.

- Setting rules for dealing with open spaces in urban areas such as; gardens and streets, by selection of; pavements, materials, lighting, colour and the architectural style.

- Applying international criteria that respect and take into consideration the movement of pedestrians and physically challenged citizens.

- Setting regulations for appropriate treatments of advertisements and signs in streets, squares and on buildings' facades.

- Re-organizing public squares within an architectural and visual framework, conforming to specific features of every area and preserving the original old form of every square.

- Discussing draft laws and addressing regulations that help to achieve urban harmony.

\subsection{Heritage Conservation Management in Alexandria}

In many places all over the world, cities like Paris, London, New York and many others have regulated heritage conservation issue and established systems that maintain identity and ensure economic growth. A previous study about heritage lose in Philadelphia; the author argues that demolition of listed historic resources through policy provisions such as economic hardship and public interest has led to increased controversy and tension in the preservation community. She explains that it is not the heritage commission that is responsible for this loss; it is the policies that are complicating the Commission's ability to protect heritage assets best (Kuntz, 2014). 
The Alexandria Preservation Trust founded in 1999 (Awad, 1999) prepared an inventory of the heritage buildings in Alexandria in need of protection from demolition. After announcing "Law 144" for the Demolition of Buildings and Heritage Conservation was officially in 2006, the Alexandria governorate established committees to identify the historical buildings and areas throughout Alexandria. The previous inventory was updated and published on January $31^{\text {st }}, 2008$ according to declaration No.278 of 2008 (Alexandrina, 2007). The official conservation list of Alexandria's Heritage inventory was officially published in the official Egyptian press, 'El Waqaa El Masreya' issue number five in 2009. It contains municipal and architectural information on buildings, streets, areas and art in the city. The list originally included 1135 registered buildings on three levels (national level- city level- local level), as well as, 73 heritage conservation sites, containing open areas and parks. There were 43 conserved streets and 134 archaeological sites and buildings when the list was first published. The listed heritage areas were combined with streets and reduced to 26 areas, and then cut again to 20 areas in 2016 (Alexandria Governorate, 2007). Now, after almost nine years, the number of listed buildings in Alexandria has dramatically shrunk. According to the Save Alex campaign ${ }^{\dagger}$, at least 36 buildings have been destroyed in the past five years since the 2011 Egyptian Revolution. This number is expected to rise distinctly soon, with 20 further properties removed from a heritage building list.

This heritage conservation inventory restricts the demolition of listed buildings and regulates dealing with them only through the local administrative authority. The Technical Secretariat of the Standing Committee of the Heritage Conservation Commission in Alexandria is the only governmental body responsible for any issues regarding heritage buildings and sites. However, there is no heritage management system in Alexandria. In fact, the whole country follows the unified law "Law no.144".

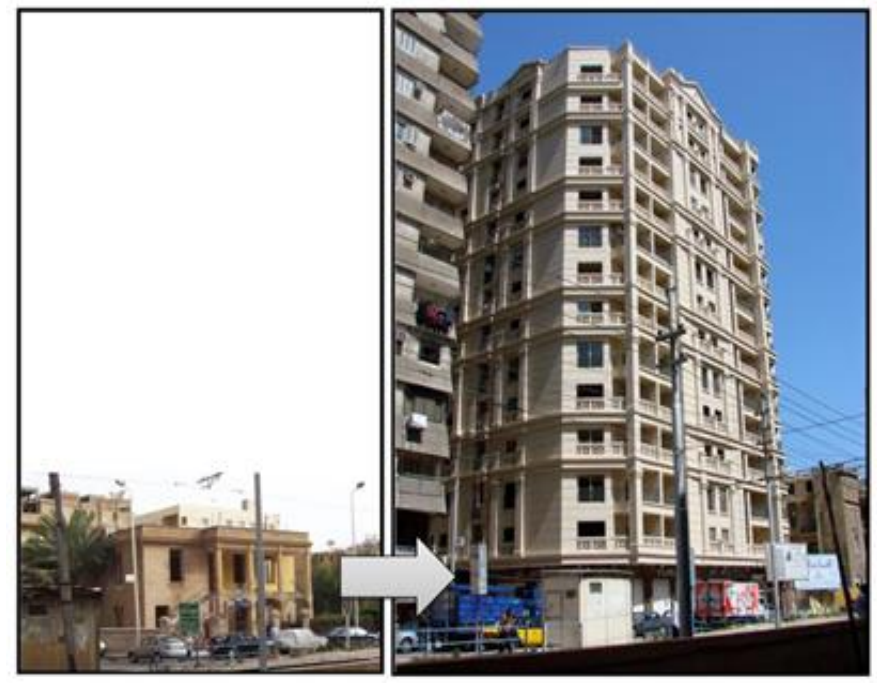

Fig. 1. A small villa in El-Raml area demolished to make way for a huge apartment building. Source: internet picture

Therefore, limited information is available for owners and investors on how to manage heritage in Alexandria. The only given information is allowed building heights and areas, leaving owners with no choice except to try to get their buildings out of the Heritage list, or illegally demolishing them under the name of unsafe structures. Many court cases in this matter are revoked in the event of a conflict between the specific requirements and the rights given to citizens by the Egyptian constitution. This situation points the fact that it is not the Committee but the policies that are complicating the ability to protect heritage, Fig. 1 shows how owners benefit from tearing down their villas to make way for new real estate development.

\footnotetext{
† Save Alex was launched in 2012, a local Alexandrian group committed to protecting and enhancing the built environment of the city of Alexandria. It aims at increasing public awareness of what is left of Alexandria's rich architectural heritage. 


\subsection{The Technical Secretariat of the Standing Committee of the Heritage Conservation Commission in Alexandria}

Since the establishment of the Heritage Committee in 2009, it is providing technical support for heritage conservation in the following manners (Harmony, 2009):

- Studying building files and giving recommendations to the concerned authorities on restoration and new building permits in conservation areas.

- Preparing technical reports for the defence against lawsuits filed by owners to take out buildings from the Heritage list.

- Preparing technical reports and determining the structural status, thus, treatment methods needed in conservation work.

- Preparing guidelines for heritage conservation areas in Alexandria, according to the standards and basis of The National Organization of Urban Harmony for heritage buildings and sites.

Although the committee's technical support for heritage; the city has lost many buildings from the Heritage list in the past years through court orders, or by illegal demolition. Losing heritage through policy provisions such as public interest has led to increased arguments about how efficient is heritage managed in Alexandria. Bureaucracy and corruption are some of the reasons for this loss. However, merits are not the issue of concern in this research. The discussion focuses on fixing the structure of the inventory, to deal with and conserve heritage by eliminating adverse interest, taking into consideration needs of both the real-estate sector and the public.

The methodology used in 2006 for preparing the Heritage Building inventory of Alexandria relied only on recording every building that has historical, architectural or constructional value. It was meant to list as much as possible of buildings and areas so that they will be prevented from demolition by law and that if some were demolished, the city would still have more to save. Therefore, and according to" Law 144", all buildings related to famous characters or historical eras, as well as areas of particular urban fabric or architecture style were listed, thus prevented from demolition. The Listing was divided into three levels which are: local, city and national level, depending on the degree of importance. Approved maps by declaration 278 of the year 2008 containing listed buildings and areas were distributed to local authorities all over the city. According to that; dealing with any of these buildings or areas must go through the "Technical Secretariat of the Standing Committee of the Heritage Conservation Commission in Alexandria" as the only governmental body responsible for heritage management in Alexandria.

\section{Findings}

\subsection{The Real-Estate Market in Alexandria}

Alexandria is home to about 4.604 million inhabitants by the year 2017 (Planning, 1997). The city has natural geographic boundaries that prevent it from extension to the North, East and South as clarified in the satellite image of Fig. 2. From the north, the city has a long and fascinating waterfront opened to the Mediterranean Sea. From the south, it is bordered by the Marriott Lake. The eastern urban sprawl of the city is limited because it destroys fertile agricultural lands of the Nile Delta. The only legal expansion available for the city to grow is to its west coast and toward the new city of 'Borg El-Arab' located in the south-west. This situation resulted in extending the length of the city to exceed 35 kilometres along the sea coast. ((GOPP), 2012)

With rapidly growing population, Alexandria became more crowded, suffering from pressures on infrastructure, transportation and with little land available for building affordable housing. To make up the difference between supply and demand, real-estate developers take the risk of illegally increasing building heights and demolishing heritage buildings to make way for new investments in the city core. They are taking advantage of the weakness in state control, especially after the 2011 Egypt Revolution, to increase their profits, adding more pressure on the city's deteriorated infrastructure. These violations resulted in the widespread of illegality in the building sector. 
According to the Egyptian General Authority for Investment (GAFI) (INVESTMENT, 2015), it is important to note that, real estate is one of the most important sectors contributing to economic growth in Egypt, affecting more than 90 industries related to construction. It is considered a labour-intensive sector as it accommodates at least $8 \%$ of the total labour force. The value of real estate investments in Egypt has witnessed continuous increases since 2001. In Alexandria, and due to the previously mentioned city growth boundaries, the demand for new apartments triggered investors to become greedier, breaking the law to obtain high profits. This situation resulted in the widespread of illegality in the building sector. So, are we talking the same language, Heritage conservation versus real estate development?

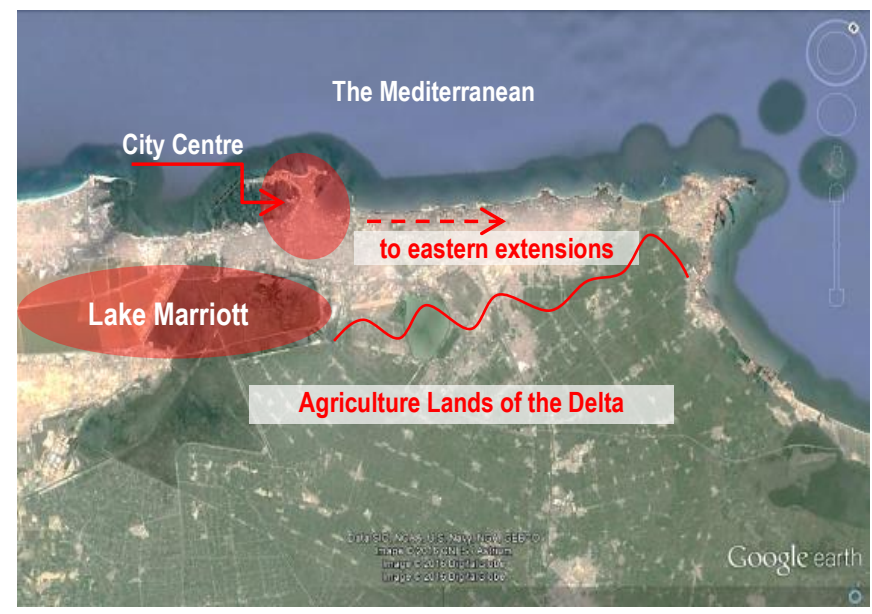

Fig. 2. Satellite image demonstrating Alexandria City with its natural growth boundaries. Source: Google Maps

\subsection{Problems Facing the Heritage Conservation List in Alexandria}

The locale government in Alexandria is working on finding new solutions for transportation problems to help reduce the pressure on streets and the need for new affordable residential units in the city core by adding new urban expansion zones presented in the Strategic Urban Plan of Alexandria 2032. The government is also looking for fast solutions to deal with Building violations that reached 27 thousand building violations from $2005-2015$. This situation calls for creative solutions to eradicate violations in the building sector and guarantee conservation of what is left of the city's heritage. To sum the problematic issues of the heritage conservation list in Alexandria, some observations were recorded as follows $\ddagger$ :

- The list does not include building owners; it does not discuss with them, at any stage, the possibilities, and advantages of owning a listed building. Due to ignorance, owners are frustrated. Many have raised court orders against the governorate and the heritage committee to remove their buildings from the Heritage list, in which many have won because of weak reasoning.

- Registering as much as possible of significant old buildings overlooked the fact that there are some listed villas located on streets that have been developed into high-rise apartment buildings occupying $100 \%$ of their land lots. The villas are deprived of their original settings, surrounded by high walls from three sides, thus completely becoming out of context.

- In many cases, it was noticed that the list contains many old buildings that have similar features, representing the same age and style, but scattered all over the city, without logical explanation of why they were all listed.

\footnotetext{
₹ The author is a member of the Technical Secretariat of the Standing Committee of the Heritage Conservation Commission in Alexandria since its establishment in 2009. 
- The maps containing the listed buildings and areas were not revised with city planning scheme, prepared by the General Authority for Urban Planning in Egypt. Therefore, no actions were taken to protect scattered listed buildings and areas from local zoning regulations.

- Although "Law 119" stated to; "identify areas of outstanding value and set the criteria used for their selection, maintenance programs, implementation mechanisms and funding resources". Also that; "the organisation sets up rules and conditions for conservation of areas, buildings, and structures of outstanding value. The Supreme Council of Urban Planning and Development shall issue a decree with these rules. The concerned bodies shall comply with these rules whenever they undertake works in one of these areas, buildings or structures". However, because laws in Egypt work as separate islands, such restrictions are overlooked.

The most important remark that was overlooked and put aside while completing the Heritage list in Alexandria, and even Egypt as a whole, is the issue of compensation for owners of registered buildings. This important catalyst for heritage conservation, although mentioned in the previously mentioned Law "to set the criteria for funding resources", it is still being discussed at the national level, after a decade of laws and orders to save architecture heritage in Egypt (Nassar, PhD, 2006).

In conclusion, the Heritage list of buildings and areas prepared in 2009 requires revision to address each identified problem. After almost nine years, it is crucial to re-establish the list, taking into consideration solutions to problems that resulted from neglecting the needs of the local society of owners, users and investors. To tighten the gap between heritage conservation and real estate development, planning, land, buildings and heritage needs to be put under one roof, through establishing a new development bureau that makes it possible to find the standing point between development and preservation (Li, 2008).

\section{Discussion And Analysis}

\section{Case Study on Heritage Conservation Management in San Stefano Neighbourhood}

San Stefano' case study presents the discussion in this research about how to deal with certain villas in the list, which still exists in the area, although they have lost their original setting and contest. The reasons for selecting this area as a case study are as following:

- Represent an example of an area in the city that more than $95 \%$ of its built up environment has changed.

- Represent an area that had certain cultural heritage associated with a building typology linked to a certain social class that has disappeared.

- Availability of data and information on the area with continued monitoring of changes over the last four decades.

- The absence of any heritage listed areas of special building recommendation and just a limited number of listed buildings on the local level.

\subsection{The Administration Structure}

When the tram network was first established in 1860, it was the first in Africa; the city extended to the east towards the sandy beaches of 'El-Raml'. The tram was the key driver for linear urban growth eastwards along the Mediterranean coastline. By 1930 'El-Raml' area had developed into a veritable green suburb of Alexandria ((GOPP), 2012). Alexandria Governorate has now divided administratively into seven districts. Each district contains some sub-districts. These sub-districts are divided down to 139 municipalities, which are the smallest subdivision upon data is collected and analysed by The Central Agency for Public Mobilization and Statistics as demonstrated in Fig. 3.

The Eastern District is one most important area in the city. It contains vital facilities such as; Alexandria International Airport and 'Sidi Gaber' train station. It also has the most prestigious neighbourhoods in the city such as 'Gianaclis', 'Glim', 'Kafr Abdu', 'Louran', 'Roshdy', 'San Stefano', Stanley, and 'Zezenia'. In neighbourhoods like 'Roushdy' and 'Kafr Abdu', one can still find old villas and palaces built by wealthy businessmen of the early $20^{\text {th }}$ 
century, many of whom were of Greek, British or Italian descent. 'El-Raml' tram runs through this district from east to west, connecting the Eastern District with Middle District and Western District. The Eastern District contains $40 \%$ of the number of listed buildings in the heritage conservation inventory. It also contains two of the twentieth Heritage listed areas in Alexandria. Almost all listed buildings in 'El-Raml' are villas and palaces.

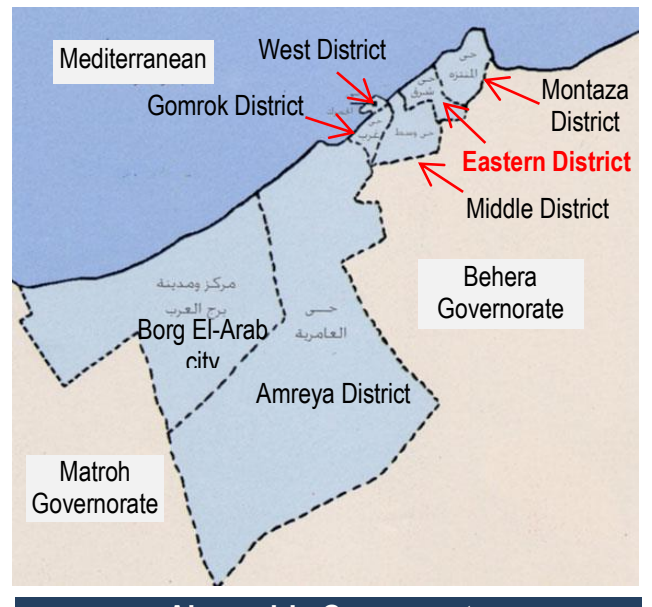

\section{Alexandria Governorate}

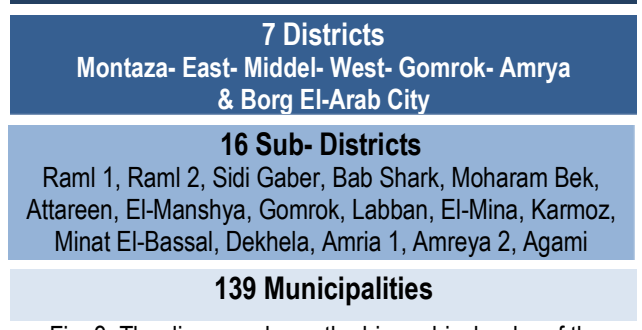

Fig. 3. The diagram shows the hierarchical order of the administrative entities in the Governorate of Alexandria. Source: SUP ALEX 32

\subsection{The Heritage of San Stefano Neighbourhood}

'San Stefano' is part of the greater 'El-Raml' area, which represents the cities extension to the east in the late $18^{\text {th }}$ century. At that time, the area consisted of some villas and palaces for the elite society. Alexandria's waterfront promenade at 'El-Raml' area was not built till the beginning of the $20^{\text {th }}$ century. The Tram line which connected the City Centre to 'El-Raml' on the east ended at 'San Stefano' area in1800 and then later extended to the east.

'San Stefano' neighbourhood is named after a chapel dedicated to 'St. Stefan' built by Count Etienne or 'Istvan Zezenia' in 1863. It was demolished in the mid-eighties. He also built the well-known 'San Stefano' hotel that was inaugurated by the Khedive 'Tawfiq' on June 26, 1887. The casino and hotel resembled the architectural style of resorts in the south of France at that time, see Fig. 4. It was subsequently modified and remodelled throughout the years till it lost all its architectural features in the 1980s, and it was officially shut down in 1993 (Farag, 1998) (Rafaat, 1999). The 'San Stefano' Hotel and casino witnessed many significant events in the history of the city and even in the whole of Egypt. However, the building was demolished in the 1990s to make way for a new Four Season Hotel, Grand Mall, and luxuries residential apartments, see Fig. 5. This new complex still holds the name of San Stefano. The huge building is now considered a landmark for Alexandra's $21^{\text {st }}$-century real-estate development. 


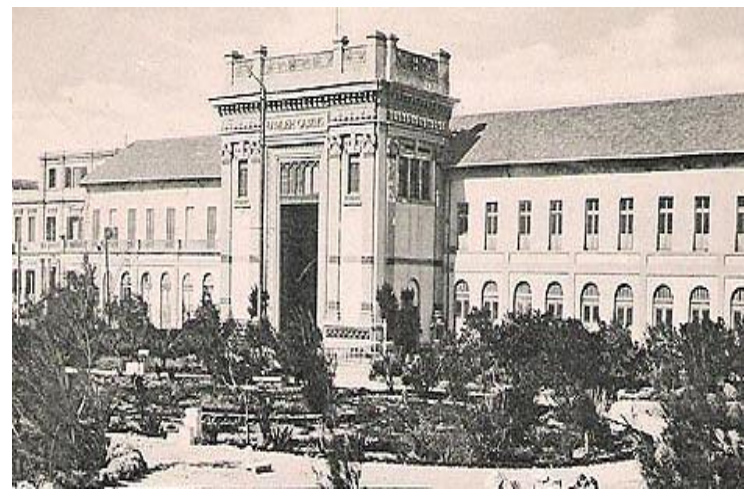

Fig. 4. A Sea view picture of the old demolished San Stefano hotel and Casino.

Source: Four-season Alexandria web site

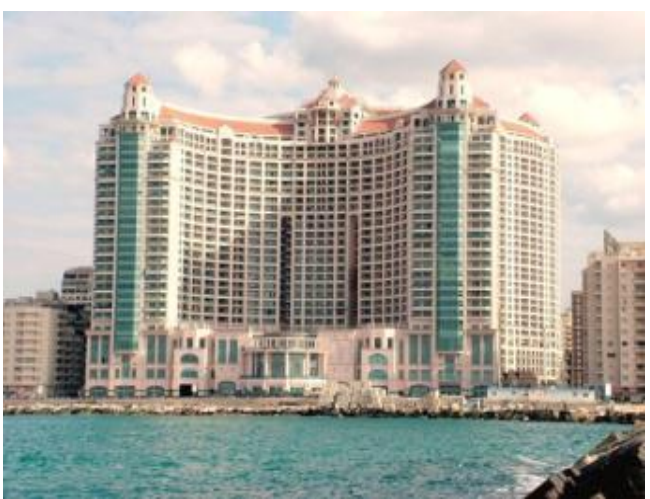

Fig. 5. A Sea view picture of the new Four Season hotel, mall and apartment building at San Stefano. Source: internet image

\subsection{The Listed Buildings and the Development Situation}

According to the Heritage list of Alexandria, 'San Stefano' area contains only three listed buildings. These buildings are scattered and dispersed in the area between new apartment buildings. Unfortunately, these buildings are totally deprived from their original setting, surrounded by high residential buildings that alter their privacy and value, as seen in Fig. 6. On the other hand, these three buildings are listed on the local level, and two of them did not exist before the 1940's thus, their architectural value is not of importance. On the other hand, the strategic urban plans of Alexandria did not point out special regulations for this area or similar surrounding areas, to maintain their typology as a low rise of villa zones. Even the current Heritage list did not point out special recommendations to 'San Stefano'
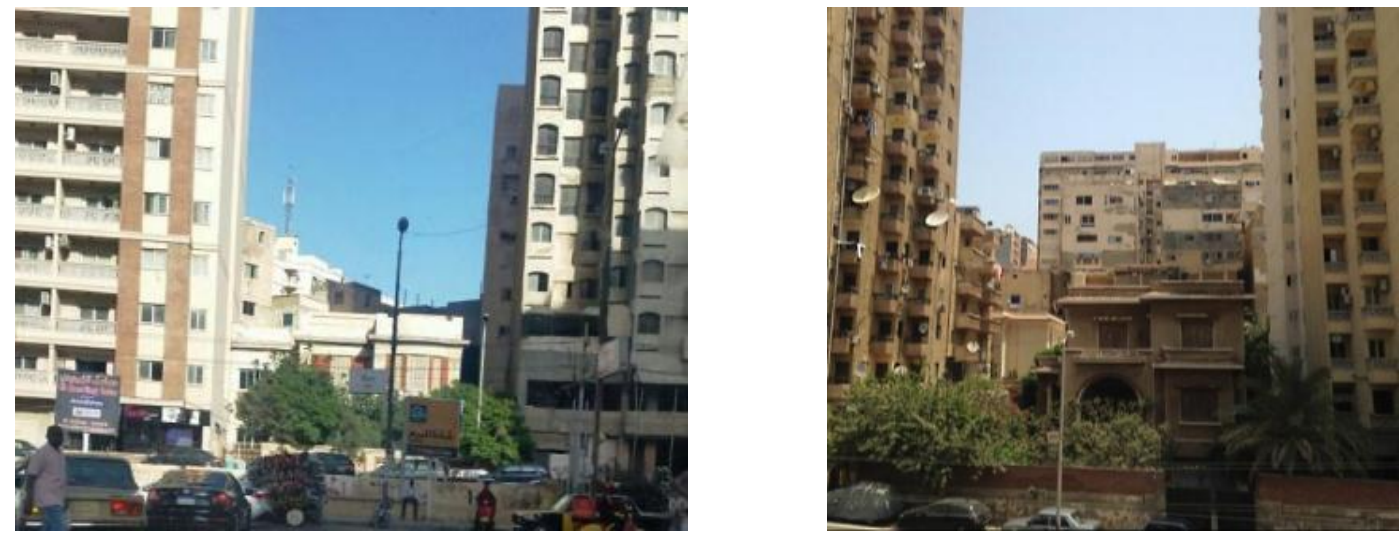

Fig. 6. Two listed buildings at San Stefano deprived from their original setting. Source: author

neighbourhood or many surrounding areas. The only confined three listed areas at 'El-Raml' with restricted building heights not to exceed 12 metres and max. 60\% footprints are at 'Kafr Abdo', 'Roshdy', and 'Zezenia'.

Analysing of the current situation map of the 'San Stefano' municipality and its surrounding neighbourhoods altogether, proves that is a combination of four main neighbourhoods as shown in Fig. 7; 'Gelim', 'Zezenia', 'San Stefano', and 'Loran'. According to the Strategic Urban Plan Alexandria 2032, San Stefano municipality is currently middle to a high-class residential area, with high density vertical residential buildings (8-12 storeys) and a gross density of 496 inhabitants / Feddan. The urban fabric consists of narrow 4-10 meters streets, which used to contain only villas. Now the remaining villas in the municipality (registered and not registered) represent $4 \%$ of the total built 
up area of $968.286 \mathrm{~m}^{2}$ and the total number listed villas are 45 . These heritage buildings are suffering from neglect. They became odd to their surrounding neighbours. They lack privacy and security, entirely deprived of their original surroundings at the time they were built. Their value is only to their land price as potentials for new developments.

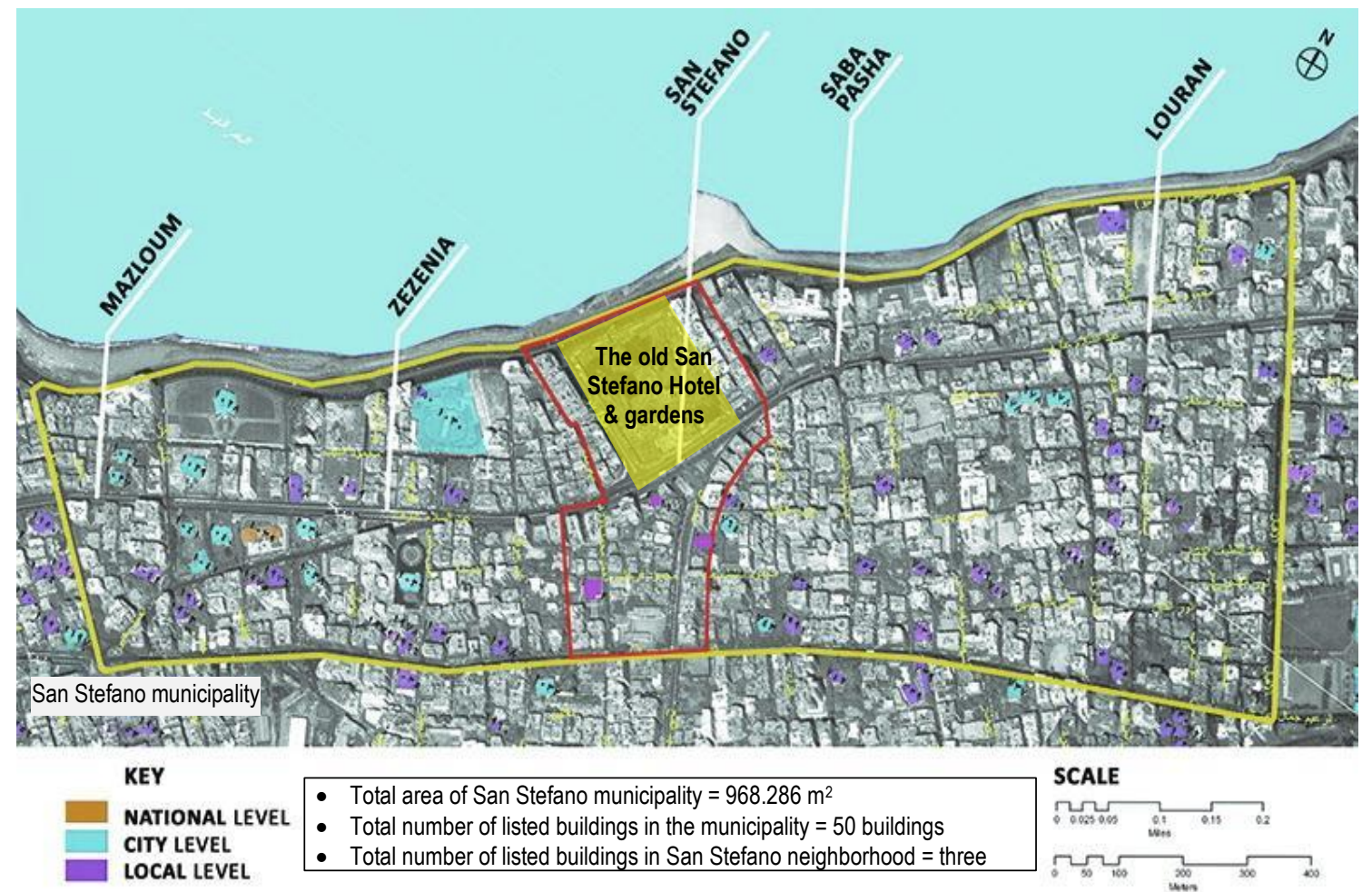

Fig. 7. New satellite image of San Stefano Municipality and neighbourhood, highlighting the current available listed villas today on three levels. The yellow line defines the municipality and the red line defines San-Stefano neighbourhood, with the hotel highlighted in yellow. Source: the Heritage list of Alexandria modified by the author.

According to the two cadastral maps of 1908 and 1934 in Figures 8, 9, the urban fabric of the area totally consisted of villas. From analysing these maps and the current satellite image, one can point out many issues; first the location of the existing listed buildings, thus their contextual situation is completely changed. Most of these villas were listed for their architectural value. After years of neglect and lace of maintenance most of the architectural features are lost. The map also shows how the urban fabric of the area completely changed, with the remaining villas occupying only $4 \%$ of the total built up area. Plus the streets and the urban fabric is now more dense, leaving those scattered villas with no privacy. Unfortunately, some of them destroy the harmony of modernised streets. On the heritage administrative level, Alexandria's heritage conservation listing did not provide any means to ensure sustainability for the listed villas at San-Stefano. Listing only prevents their demolition by law, adding to that more suffering to their owners, because they have no advantages for keeping their buildings. 'San Stefano' municipality is one example of many other places in Alexandria city in need of re-evaluating the listed buildings and their zoning requirements, regarding heritage conservation. 


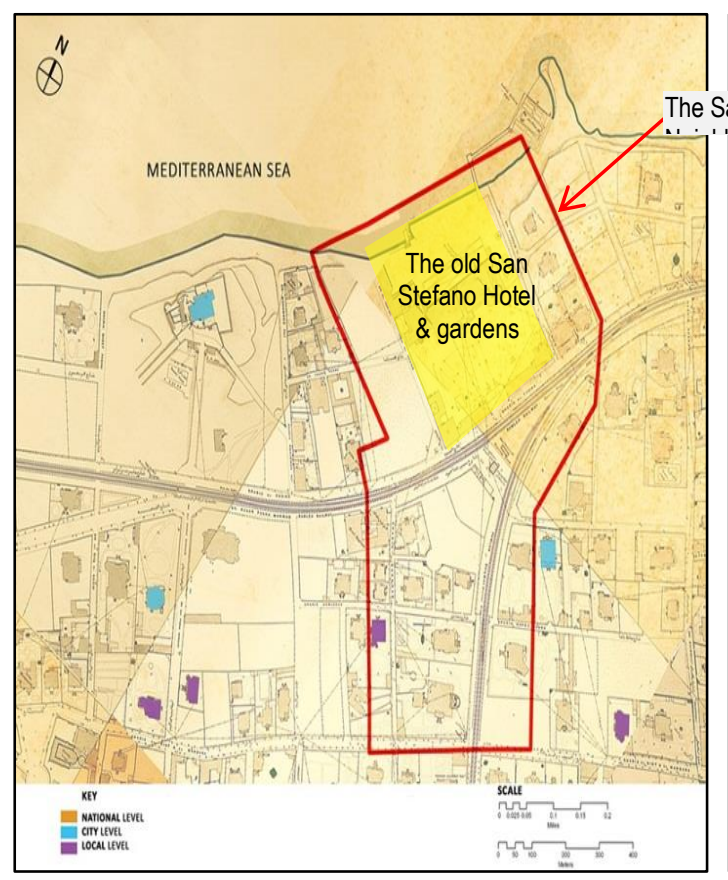

Fig. 8. Image of the old cadastral maps of 1908 presenting the available villas at that time, with the highlight on the remaining listed ones today.

Source: Maps of Alexandria edited by the author

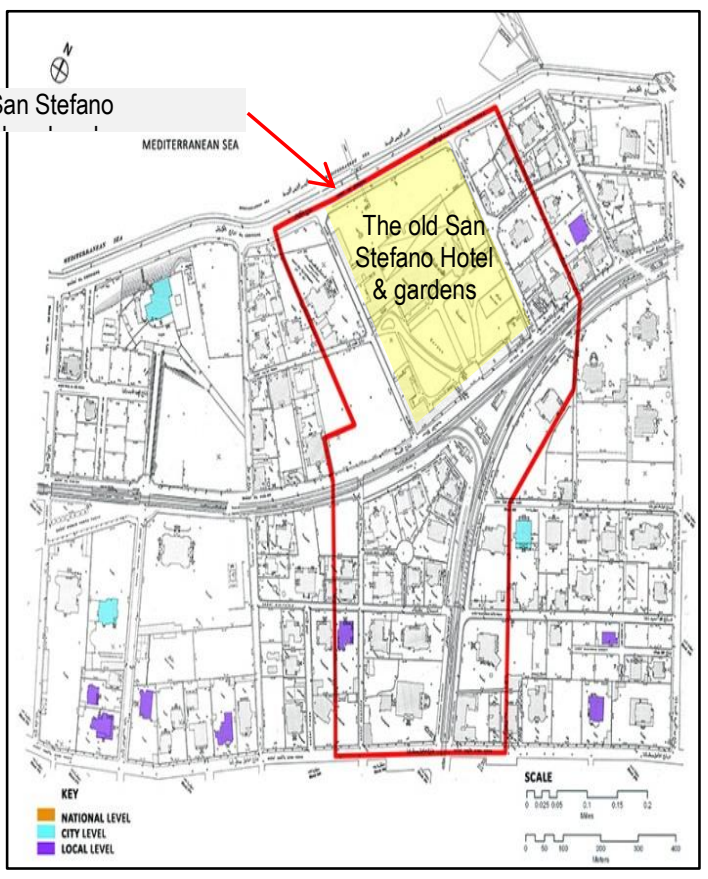

Fig. 9. Image of the old cadastral maps of 1937 presenting the available villas at that time, with the highlight on the remaining listed ones today.

Source: Maps of Alexandria edited by the author

\section{Conclusion and Recommendations}

Approaches towards saving Alexandria's heritage to secure them from neglect and demolition must urgently focus on opening a variety of development and incentive ideas for owners and investors. In previous research studies before the announcement of the "Law 144 for the year 2006", author of this research stated that; "to put down a fair and substantial legislative system for heritage conservation, users and the public should benefit from conserving their assets". The ideas of sustainable heritage conservation and adaptive re-use are the best solutions in many cases. Another more recently published research in Alexandria argues managing tensions between owners and legislations in the heritage conservation system stated that; the top-to-bottom approach used in Egypt's political system, especially in heritage management resulted in the absence of fairness and legitimacy in the relationship between owners and the conservation system (Elsordy, 2011).

This research recommends putting new criteria for the selection of listed buildings. Therefore, the current inventory must then be reviewed based on;

- The owner, investor and user awareness and discussion, with local state and NGOs to suggest creative solutions and uses for heritage building according to local needs and economy.

- Old villas at 'El-Raml' must be grouped and recognised as evidence of the forgone era. Therefore, any villa that is totally deprived of its original setting according to urban standards must be reconsidered in the inventory.

- Community awareness through establishing local groups for (case-by-case) solutions and execution. Spreading the culture of heritage conservation must start from school children to governmental administrations, shop owners, and ordinary citizens. 
- The conservation authority in Alexandria must focus on groups and areas of cultural heritage in the city and put different programs, with reuse ideas, initial feasibility studies and incentive programs. Aiming specifically on local societies, with information on how to invest in heritage buildings, because Real-estate investors in Alexandria are an important sector that needs to be approached.

This approach is based on four major steps; first; the establishment of the new compensation system for listed building owners that takes into account new innovative solutions. Second; the encouragement of adaptive reuse projects on heritage buildings by enforcing local laws that guaranty beneficial rights for both owners and investors. Third; filtering the heritage conservation list of Alexandria to analyse the situations of scattered listed buildings, which are registered only at the local level, and which have lost their original settings, thus became obstacles towards harmonising the image of some streets or areas. Four; establishing a new development bureau which puts planning, land, buildings, works and heritage under one roof to make possible the cooperation between development and preservation.

Egypt's urbanisation problems have accumulated and complicated to the degree that the search for solutions on national levels needs concerted efforts among state institutions, civil society, and the private sector. Preserving the architectural heritage is now becoming a cultural challenge in need for innovative planning, architectural and economical solutions. Therefore, the approaches to conservation must shift from saving architectural heritage to fulfilling the local needs as the only solution to manage heritage conservation with real estate development.

\section{Acknowledgment}

The author wishes to acknowledge 'Arch. Marwa Kamel El-Sayed', demonstrator at the Architectural Engineering Department, Faculty of Engineering, Pharos University in Alexandria for her efforts in preparing the maps in this paper as well as her enormous support to the author in bringing out the work as intended.

\section{References}

(GOPP), G. O. (2012). SUP Alexandria 2032. Alexandria: General Organization of Physical Planning (GOPP).

Ahmad Ezanee Hashim, H. A. (2012). Functional Assessment through Post Occupancy Review on Refurbished Historical Public Building in Kuala Lumpur. Procedia - Social and Behavioral Sciences, 330-340.

Aidatul Fadzlin Bakria, N. A. (2012). Managing Heritage Assets: Issues, challenges and the future of historic Bukit Jugra, Selangor. Procedia - Social and Behavioral Sciences, 341-352.

Alexandria Governorate, A. (2007). The Heritage Conservation List of Alexandria. Alexandria: Bibliotheca Alexandrina.

Alexandrina, B. (2007). Alex-Med. Retrieved May 15, 2014, from Bibliotheca Alexandrina: http://www.bibalex.org/alexmed/Projects/

Arab Republic of Egypt, \& Regional Planning Center Alexandria. (2012). Strategic Urban Plan Alexandria 2032 - Alexandria SUP 2032. Alexandria: the General Organization for Physical Planning (GOPP).

Aref, Y. G. (2007). Alexandria's Forgotten Architecture - Defensive buildings of Alexandria. First Euro Mediterranean Regional Conference, Traditional Mediterranean Architecture. Present and Future. Barcelona: Rehabimed.

Awad, M. (1999). Alexandria Preservation Trust. Retrieved May 15, 2014, from http://pharos.bu.edu/Alex/apt/

Bruce Ferguson, J. N. (2003). A financial framework for reducing slums: lessons from experience in Latin America. Environment and Urbanization, 201-215.

Bullen, P. A. (2007). Adaptive Reuse and Sustainability of Commercial Buildings. Facilities, 20-31. 
Christian Barillet, T. J. (2006). Cultural Heritage and Local Development. France: CRATerre-ENSAG/Convention France-UNESCO.

Culture, m. o. (2001). National Organization for Urban Harmony. Retrieved May 15, 2014, from http://www.urbanharmony.org/

Elsordy, D. A. (2011). Heritage conservation in Alexandria. Egypt: managing tentions between ownership and legislation.

Intrenational Journal of Heritage Studies, 497-513.

Farag, F. (1998, November 12). A final Adieu. Retrieved from Al-Ahram Weekly.

Harlina Mohamad Ali, M. M. (2012). Self-Sufficient Community through the Concepts of Collective Living and Universal Housing. Procedia - Social and Behavioral Sciences, 615-627.

Harmony, U. (2009). the Technical Secretariat of the Standing Committee of the Heritage Conservation Commission in Alexandria. committee No. 142 for year 2009. Alexandria: Alexandria Governorate.

Hazlina Hamdan, F. Y. (2014). Social Capital and Quality of Life in Urban Neighborhoods High Density Housing. Procedia - Social and Behavioral Sciences, 169-179.

Hilde Remoy, S. J. (2015). Adaptive Reuse of Offices - Residential Conversions in Sydney. 22th Annual European Real Estate Society (ERES) Conference. Istanbul: ERES.

Husrul Nizam Husina, A. H. (2015). Correlation Analysis of Occupants' Satisfaction and Safety Performance Level in Low Cost Housing. Procedia - Social and Behavioral Sciences, 238-248.

Ibrahim, A. A. (2012). A Decision Making Approach for Prioritizing Local Communities' Development Investments. Procedia - Social and Behavioral Sciences, 649-660.

Investment, M. o. (2012). General Authotity for Investment. Retrieved May 15, 2014, from Invest In Egypt:

http://www.gafi.gov.eg/en/default.aspx

INVESTMENT, T. M. (2015). General Authority for investment and free zones (GAFI). Retrieved March 30, 2015, from http://www.gafi.gov.eg/English/Sectors/TargetedSectors/Pages/Real-State.aspx

ISDF. (2012). About Us: The Informal Settlement Development Facility. Retrieved from The Informal Settlement Development Facility Web site: http://www.isdf.gov.eg

Jamalunlaili Abdullahab, C. B. (2015). Public Participation in the Kuala Lumpur Draft City Plan 2020. Procedia - Social and Behavioral Sciences, 70-75.

Khalifa, M. A. (2011). Redefining Slums in Egypt: Unplanned versus unsafe areas. Habitat International, 40-49.

Kuntz, S. E. (2014). Why We Demolish: Assessing Heritage Loss in Philadelphia as a Catalyst for Policy Innovation in Historic Preservation. University of Pennsylvania Scholarly Commons.

Li, P. (2008). Transfer of Development Rights Approach: Striking the Balance between Economic Development and Historic Preservation in Hong Kong. Surveying and Built Environment, 38-53.

Mason, R. (1998). Economics and Heritage Conservation. Los Angeles: The Getty Conservation Institute.

Nassar, D. (2006). PhD. Guidelines for Identification of Legislative and Financing Aspects. Alexandria: Alexandria University, Faculty of Engineering.

Nassar, D., Naguib, I., ElFakharany, M., \& Kamel, M. (2014). Project Identification Sheet. Sustainable Cities of the Mediterranean: Guiding Light from Alexandria. Alexandria: Bibliotheca Alexandrina.

Nations, U. (2001). UNESCO. Retrieved May 15, 2014, from http://www.unesco.org/

Neda Sadat Sahragard Monfared, H. H. (2015). Design principles in Sustainable Local Community with Security and Socialization Approach (Case study: Chizar). Procedia - Social and Behavioral Sciences, 62-70. 
Nurul Hidayah Chamhuri, H. A. (2012). Conceptual Framework of Urban Poverty Reduction: A review of Literature. Procedia Social and Behavioral Sciences, 804-814.

Nurul Hidayah Chamhuri, H. H. (2015). Conceptual Framework of Public Participation in Ensuring Quality of Life of the Urban Poor in Malaysia. Procedia - Social and Behavioral Sciences, 349-356.

Payne, G. (2005). Getting ahead of the game: a twin-track approach to improving existing slums and reducing the need for future slums. Environment and Urbanization, 135-146.

Planning, T. G. (1997). General plan for the city of Alexandria until 2017. Alexandria: The Ministry of Housing, Utilities and Urban Communities.

Poor, S. J. (2015). Participation, Sense of Home, and End-users' Needs in Mass Housing. Procedia - Social and Behavioral Sciences, 286-296.

Presidency, E. (2008). Ministry of Culture. Retrieved May 15, 2014, from National Organization for Urban Harmony: http://www.urbanharmony.org/

Rafaat, S. (1999, January 1). Adieu San Stefano. Retrieved from Cairo Times.

Wong, S. (2012). What have been the impacts of World Bank Community-Driven Development Programs? Washington: The World Bank. 